Самоленко Т.В., к. фіз. вих. і спорту, дои.

Київський національний торговельно-економічний університет,

м. Київ, Україна

Павлишина К.I.,

Київський національний торговельно-економічний університет, м. Київ, Україна

\title{
ВЕДЕННЯ БІЗНЕСУ В УКРАЇНІ
}

У 2002 році Світовий банк започаткував проект під назвою «Ведення бізнесу» (англ. DoingBusiness). Це рейтинг, який дозволяє визначити простоту ведення підприємницької діяльності, за такими критеріями, як: легкість відкриття нового бізнесу, оплата податків, реєстрація власності, отримання дозволу на будівництво, захист прав інвесторів, отримання електроенергії та інші. Досліжується 183 країни, в загальному рейтингу 2019 року Україна посідає 71 місце, з балом 68,25 . Найгірший показник ми маємо у категорії вирішення проблем неплатоспроможності - 145 місце (31,37 балів), найкращий -показник отримання дозволу на будівництво - 30 місце (76,91 балів). За 10 років Україна піднялась в рейтингу на 74 позиції, тобто в 2009 році в загальному рейтингу вона була на 145 місці.

До найбільш вагомих переваг ведення бізнесу в Україні можна віднести: спрощену систему оподаткування, мінімальну ставку оподаткування, просту звітність, відносно дешевий ринок праці, встановлення мораторію на перевірку бізнесу по 2017 рік.За індексом оподаткування Україна займає 54 місце. Порівняно 32017 роком позиція в цьому рейтингу знизилась, основним недоліком податкового законодавства України є його складність та нестабільність.

Також $є$ позитивні тенції пов'язані 3 реформами податкової системи та прийняттям Податкового кодексу. Позиції країни зміцнились після спрощення адмінстрування обов'язкових платежів через введення електронної звітності платежів. Залежно від річного доходу, юридичні та фізичні особи самостійно обирають спрощену систему оподаткування та групу платників єдиного податку. Спрощена система оподаткування допускаєтьсяпри річному обороті близькоодного мільйона доларів США. Але багато бізнесменів, 
адаптувавшись, знайшли спосіб обходити і це обмеження виходячи далеко за межі такого обсягу готового обороту.

В Україні встановлено 4 групи єдиного податку. Залежно від групи платника єдиного податку застосовується фіксована або процентна ставка опадаткування. Для 1-2 груп вона встановлена на рівні 10\% (121,80 грн) і відповідно, 20\% (243,60 грн) від розміру мінімальної заробітної плати на місяць. Для 3-4 груп - у відсотковому співвідношенні від валого доходу: $2 \%$ у випадку використання єдиного податку, і 4\% у разі сплати ПДВ. Наприклад, ведення бізнесу в Україні по 2 групі при обороті 1,5 млн грн обійдеться іноземцеві всього в 2923,20 грн в рік. Для підприємств 3 групи спрощеного опадаткування, при обороті близько 1 мільйона доларів США - 4\% від доходу. Особливі і не менш привабливі умови для 4 групи єдиного податку - використовується спеціальнно для сільскогосподарських виробників[1].

Податковий звітний період для платників єдиного податку в Україні першої, другої та четвертої груп - один календарний рік, а для третьої групи - календарний квартал. При цьому, один раз на рік дозволяється сплатити податки наперед.Також ведення бізнесу в Україні вигідно для власників підприємств тому, що у нас відносно дешевий ринок праці. Заробітна плата порівняно з країнами Свропи невисока.

Серед регіонів України, найпривабливішою у рейтингу за легкістю ведення бізнесу є Сумська область, далі йде Львівська, ІваноФранківська, Кіровоградська, останню позицію займає Луганська. За умовами створення підприємства також лідирує Сумська область. Ця процедура займає 6 днів із витратами 343 гривні. Чернівецька область лідирує за одержанням дозволу на будівництво. Витрати у часі складають 96 днів, грошові витрати - 263810 гривень. Останню позицію займає Чернігівська область - 116 днів та 367079 гривень. У рейтингу оформлення земельної ділянки перше місце займає Львівська область -31 день та 11180 гривень, останнє - Харківщина 161 день та 18915 гривень витрат.

Приєднатися до електромережі у Волинській області можна всього за 22 дні та 87360 гривень, а в Київській області це буде набагато дорожче - 599760 гривень, хоча й за той самий період [2]. Таким чином, в Україні спостерігається покращення позицій у міжнарожних рейтингах, удосконалення системи оподаткування. 


\section{Список бібліографічних посилань}

1. Податковий кодекс України. пункт 295.8 статті 295 в редакції Закону № 71-VIII від 28.12.2014; зі змінами, внесеними згідно із Законом № 1797-VIII від 21.12.2016.

2. REGIONALDOINGBUSINESS-201 7[Електронний ресурс]. Режим доступу : http://brdo.com.ua/wp-content/uploads/2017/05/ Regional-Doing-Business_obshhyy-2.pdf 